\title{
The Impact Mechanism of Executive Incentive on Corporate Environmental Performance
}

\author{
Rong Wang ${ }^{1, *}$ Liangcan Liu $^{2}$ \\ ${ }^{1}$ School of Business Administration, Guizhou University of Finance and Economics, Guiyang, Guizhou, 550000, \\ China \\ ${ }^{2}$ School of Business Administration, Guizhou University of Finance and Economics, Guiyang, Guizhou, 550000, \\ China \\ *Corresponding author. Email: wr1997@qq.com
}

\begin{abstract}
In China's green governance project, enterprises occupy a dominant position. In recent years, in the field of corporate governance, executive incentive have become a common concern for academics and business owners. Therefore, how to formulate a reasonable and sound incentive mechanism to encourage executives to make more efforts in environmental governance, thereby improving environmental performance, has become the theme of this article. Instead of using external factors as the research theme in the previous studies, we take internal governance of enterprises as our main perspective, and use the literature research method to draw conclusions: excessive executive compensation incentive can inhibit corporate environmental performance; Appropriate equity incentive can promote the improvement of environmental performance; Compared with a single incentive method, the combination of two is more conducive. Therefore, in order to improve environmental performance, we suggest that enterprises should reasonably set the level of executive compensation, make good use of equity incentive, and effectively use a combination of incentive.
\end{abstract}

Keywords: Executive incentive, Equity incentive, Environmental performance, Green governance.

\section{INTRODUCTION}

Since the reform and opening up, China's economic and social construction has made remarkable achievements. But at the same time, in the process of seeking economic development and improving economic performance, some enterprises ignore the environmental pollution behavior in the process of daily production and operation, which has caused irreparable damage to the ecology. Nowadays, the contradiction between economic construction and ecological environment has become increasingly prominent. Environmental pollution and ecological imbalance have become a new bottleneck restricting China's economic and social development.

On the one hand, although China has achieved considerable results in environmental governance, the environmental performance index 2020 report jointly released by Yale University and other research institutions shows that China ranks 120th with a score of 37.3 among the 180 countries and regions participating in the evaluation. In the face of the severe environmental problems in China, Chinese government proposed that we should 'build an environmental governance system with government led, enterprises as the main body, social organizations and the public participating'. It not only emphasizes the government's responsibility in environmental governance, but also clarifies the irreplaceable position of industrial and commercial enterprises as the main body of social production in environmental governance. At present, the novel coronavirus pneumonia has been effectively controlled, but with the resumption of the whole society, there are retaliatory pollution in some areas. As the main body of the ecological environment management system, how to improve the environmental performance and enhance the sustainable development ability of enterprises has become a strategic problem that managers should think about.

On the other hand, in the context of the current situation of environmental governance in China, listed companies, especially those with heavy pollution, as the main body of environmental governance, in order to 
maintain the interests and image of the company, comply with the call of the state, what measures should be taken to improve the environmental performance has become a common concern for business owners and operators. Cordeiro (2007) pointed out that the senior management of heavily polluting enterprises bears more severe environmental protection pressure and risks. In the context of the deepening of the separation of ownership and management in modern enterprises, senior executives, as the decision-makers of major strategies, have an important impact on the daily business activities and enterprise performance. With the development of principal-agent theory, how to alleviate the conflict of interests between shareholders and executives has become an important issue in the field of corporate governance. In recent years, there are more and more researches on executives, and the formulation of executive incentive mechanism is an important part of corporate governance system. A sound executive incentive system can not only make the interests of executives and shareholders converge to effectively solve the principal-agent problem, but also encourage executives to focus on maximizing the long-term interests of enterprises and take positive environmental management decisions, so as to improve the environmental performance of enterprises. It can be seen that in the crucial period of China's ecological environment defense project, taking China's heavily polluted listed companies as an example, from the perspective of executive incentive, exploring the internal influencing factors of enterprise environmental performance is an important topic to enhance the green development ability of enterprises and enhance the sustainable development ability of China's economy, which has important practical significance to solve the problems of environmental pollution and resource consumption.

\section{CORPORATE ENVIRONMENTAL PERFORMANCE}

\subsection{Definition of Corporate Environmental Performance}

Regarding the definition of corporate environmental performance, academic community has not reached a consensus yet. Among them, the evaluation standards that are widely recognized internationally are the environmental management system certification ISO14001(1999) standard and the environmental performance measurement standard proposed by the World Council for Sustainable Development (WBCSD) (2002). Environmental management system certification ISO14001 defines environmental performance as: an organization realizes effective environmental management by controlling its environmental elements in accordance with its own environmental goals and policies. The World Council for Sustainable
Development (WBCSD)proposed that corporate environmental performance refers to the gradual reduction of the impact on the natural environment and the use of resources during the production and operation of the company. Advocating the use of eco-efficiency indicators to measure the environmental performance of a company, and specifically quantify the environmental performance of the company by measuring the value of the company's products or services, the impact on the environment in the process of creating products or services, and the impact on the environment in the process of using products or services.

In addition to organizational structures, scholars have also defined corporate environmental performance from different perspectives. From the perspective of the comparison of environmental performance between different enterprises, Tyteca (1997) stated that environmental performance is an evaluation index for measuring the pollutant emissions of enterprises. Based on this indicator, it can reflect the differences in environmental performance between enterprises, thus making society intuitively feel the differences in environmental characteristics between different companies [1]. From the perspective of the internal management of an enterprise, Klassen \& McLaughlin (1996) pointed out that environmental performance is the final result of a series of activities such as prior control of pollution output, comprehensive treatment afterwards, or recycling in production activities. Contributions to pollution prevention and environmental protection [2].

\subsection{Measurement of Corporate Environmental Performance}

Regarding the measurement of corporate environmental performance, a relatively complete evaluation system has not been formed yet. Therefore, the academic world has adopted different quantitative methods when studying the environmental performance of enterprises. It is mainly divided into two methods: single-dimensional indicators and multi-dimensional construction of comprehensive evaluation indicators. For scholars studying the performance of companies in the USA, considering the availability of the pollution database officially disclosed by the U.S. Environmental Protection Agency and the environmental performance rankings published by non-profit organizations, scholars often use TRI (Toxic Substance Emissions Inventory) and CEP(Environmental Protection Product Certification) index is used to measure the environmental performance of enterprises.

However, for domestic scholars, due to the lack of systematic and scientific data sources, on the basis of the disclosure and availability of environmental information of the companies studied, scholars often construct a single or multi-dimensional environment 
from the perspective of input or output. Performance evaluation indicators. Hu Quying (2012) combined the relatively abundant pollution discharge fee data disclosed in the annual reports of listed companies with operating income data, and used the pollution discharge fee per unit of operating income as a proxy variable of environmental performance [3]. Lin Liguo and Lou Guoqiang (2014) used the corporate water and gas emissions data provided by the Shanghai Environmental Protection Agency to measure corporate environmental performance from four dimensions: excess emissions, total emissions, removals, and production [4]. Shen Hongtao et al. (2014) divided corporate environmental performance into three dimensions: pollution emissions, environmental management, and social impact, and evaluated corporate environmental performance by assigning weighted scores to eight specific indicators [5]. Li Wenjing and Lu Xiaoyan (2015) believed that it is more objective to measure the company's environmental performance by using the increase in construction-inprogress debits in the company's annual report as the company's environmental capital to measure the company's environmental performance relative to the subjective valuation scoring method [6]. Zou Hailiang et al. (2018) used the company's environmental honor, environmental complaints and violations of third-party evaluation information to measure corporate environmental performance from the two dimensions of corporate social impact and reputation [7]. Yin Jianhua et al. (2020) proposed that in order to comply with the practice of foreign scholars using the U.S. TRI indicator as a proxy variable for environmental performance, when domestic heavy polluting enterprises are taken as the research sample, the environmental performance is measured by the unit operating income sewage charge, which can more objectively reflect the status quo of corporate green governance[8].

\subsection{Summary of Research on Corporate Environmental Performance}

Scholars have actively explored the definition and evaluation criteria of environmental performance. As for the evaluation index of enterprise environmental performance, various organizations have put forward relevant evaluation standards one after another, but there is still a lack of unified standardization and practical maneuver ability, and the degree of universality is low. However, due to limited data sources, Chinese scholars mostly measure environmental performance from the perspective of input or output. Although the measurement methods are diverse and not unified, they play a guiding role in their specific conditions. Secondly, for the research on the factors affecting corporate environmental performance, most scholars chose to study the influence of external stakeholders on the environmental behavior of corporate from the perspective of external factors. Among them, the government's formal institutional regulation and informal institutional supervision have a significant impact on the corporate environmental performance. There are few studies focus on the influence of internal governance factors on corporate environmental performance, and a few existing studies only focus on the influence of corporate characteristics and corporate operating conditions on corporate environmental behavior. Therefore, from a micro perspective, we decided to explore the influence mechanism of executive incentive on corporate environmental performance.

\section{THE INFLUENCE MECHANISM OF EXECUTIVE INCENTIVE ON CORPORATE ENVIRONMENTAL PERFORMANCE}

\subsection{Executive Salary Incentive and Corporate Environmental Performance}

Based on the principal-agent theory, Fama (1980) proposed that when an agency conflict occurs, the principal can use the agent's market reputation effect to constrain the agent's behavior and encourage the agent to work hard [9]. According to the reputation model of agency theory, the market value of executives depends on their long-term performance and image. Therefore, executives must strive to create value for the enterprise, establish a good personal image to enhance their reputation in the executive market, so as to fully reflect their value in the competitive market, and eventually improve the level of salary.

On the one hand, from the existing research, enterprises fulfil their environmental responsibility mainly based on the following two potential reasons. One is the motivation of economic incentive. By improving the level of environmental performance and establishing a positive image of green governance, enterprises can gain a good reputation, expand product market share, enhance their competitiveness, and promote the improvement of financial performance. Therefore, in order to achieve better long-term business performance, fully reflect their own value in the competitive market and obtain higher income, the executives with lower salary tend to pay more attention to the sustainable development of their company and the environmental performance of the enterprise in the process of production and operation, so as to promote the improvement of enterprise environmental performance. The second is the motivation of legitimacy. According to the system theory, a good environmental performance of an enterprise can establish its advantages in environmental legitimacy, thereby avoiding negative social benefits and winning recognition from the government and society in order to establish a good and positive corporate image. When the 
salary level is low, executives tend to take positive environmental governance behavior in order to protect their own reputation along with the company's, so as to avoid legal penalties, thereby reducing the possibility of the company being subject to government environmental penalties and reputation damage.

To sum up, when the level of executive compensation is low, corporate executive compensation incentive have a positive impact on corporate environmental performance.

On the other hand, when the salary of executives is at a relatively high level, it indicates that the value of executives is fully reflected in the competitive market. At this time, executives tend to pay more attention to short-term benefits and be more self-interested. As a long-term strategic activity, corporate environmental protection strategy requires cumulative and long-term environmental investment. It is not only difficult to obtain considerable benefits in the short term, but also the results are highly uncertain. Therefore, when high salaries are given to executives, in order to maintain high salaries, executives who focus more on short-term self-stable benefits often develop negative environmental strategies, which will lead to the increase of environmental accidents, environmental penalties etc. thus leading to the reduction of the level of environmental performance.

Based on the above views, we argue that when the level of executive compensation is low, executive compensation incentive has a positive impact on corporate environmental performance; when the level of executive compensation exceeds the critical point, executive compensation incentive has a negative impact on corporate environmental performance.

\subsection{Executive Equity Incentive and Corporate Environmental Performance}

As the shortcomings of executive compensation incentive are increasingly revealed, the effectiveness and importance of equity incentive have gradually been recognized by scholars. By granting executives stock options, restricted stocks, and stock appreciation rights, business owners share the surplus value of the company and transfer operating risks, prompting executives to pay attention to the long-term development of the company. As a long-term incentive method, equity incentive can better coordinate the interests of executives and shareholders, help reduce short-term self-interested behaviors of executives, encourage executives to optimize the allocation of corporate resources, and encourage executives to attach importance to corporate social responsibility, which has a significant positive effect on environmental governance.

\subsection{Executive Incentive Combination and Corporate Environmental Performance}

The incentive effect of a single explicit incentive mechanism on executives is limited and diminishing marginally. In theory, an effective combination of incentive mechanisms has a more significant promoting effect on corporate environmental performance than a single incentive mechanism. However, imperfect incentive mechanism can easily lead to incentive mismatch, behavior distortion and environmental pollution.

As a short-term incentive, compensation incentive can bring certain benefits to executives. However, in practice, the impact of a single compensation incentive on corporate environmental performance is limited, and excessive executive compensation may even encourage executives' short-sighted behavior tendency. As a longterm incentive, equity incentive can better coordinate the interest relationship between principals and agents, it urges executives to pay more attention to the business decisions that are conducive to the long-term value of the enterprise. However, it is worth noting that when the relationship between environmental performance and financial performance is still unclear (Endrikat, 2014) [10], there is great uncertainty in the economic benefits expected by the enterprise's environmental management strategy. In other words, equity incentive may not necessarily bring monetary returns to executives. Therefore, a single equity incentive may not be able to achieve the envisaged incentive effect. Based on this, we state that an effective combination of salary incentive and equity incentive is more conducive to improving corporate environmental performance than a single incentive method, that is, in the process of influencing corporate environmental performance, the above two incentive mechanisms may be complementary.

\section{CONCLUSIONS}

Based on the above viewpoints, it can be found that different types of executive incentive have different impacts on corporate environmental performance.

Firstly, when the salary level of corporate executives is low, the interests of both executives and shareholders converge, and executives pay more attention to the improvement of corporate long-term interests. At this time, executive compensation incentive will promote the improvement of corporate environmental performance; When the level of executive compensation exceeds the critical point, it will promote the short-sighted behavior of executives, thereby inhibiting the improvement of corporate environmental performance.

In addition, as a long-term incentive method, equity incentive can better coordinate the interest relationship between the principal and the agent, prompting 
executives to pay more attention to business decisions that are conducive to the long-term value of the company, and then promote the improvement of the company's environmental performance.

Lastly, the combination of effective incentive mechanisms is more significant than a single one in promoting corporate environmental performance, and imperfect incentive mechanisms can easily lead to incentive mismatches, behavior distortions, and environmental pollution.

Therefore, if a company wants to improve its environmental performance, it is a great governance method to find the driving force from within the company, by establishing a reasonable and complete executive incentive mechanism. Specifically, firstly, companies should control the level of executive compensation within a reasonable range, to keep the impact of executive compensation incentive at a positive level. Secondly, companies should make good use of equity incentive, and encourage executives to pay more attention to the long-term interests of the company through the use of long-term incentive. Thirdly, companies can consider using a combination of effective incentive to improve their environmental performance.

\section{REFERENCES}

[1] DanielTyteca. Linear Programming Models for the Measurement of Environmental Performance of Firms-Concepts and Empirical Results[J]. Journal of Productivity Analysis, 1997, 8(2):183-197.

[2] Klassen R D, Mclaughlin C P . The Impact of Environmental Management on Firm Performance [J]. Management Science, 1996, 42(8):1199-1214.

[3] Hu Quying. Research on Relationship Between Environmental Performance and Financial Performance of Chinese Listed Companies [J]. China Population, Resources and Environment, 2012, 22(06):23-32. (In Chinese)

[4] Lin Liguo, Lou Guoqiang. The Environmental Performance of Foreign Direct Investment Firms: The Case of Shanghai [J].China Economic Quarterly, 2014, 13(02):515-536. (In Chinese)

[5] Shen Hongtao, Huang Zhen, Guo Fangru. Confess or Defense? A Study on the Relationship between Environmental Performance and Environmental Disclosure[J].Nankai

BusinessReview,2014,17(02):56-63+73.(In Chinese)

[6] Li Wenjing, Lu Xiaoyan. Do Institutional Investors Care Firm Environmental Performance? Evidence from the Most Polluting Chinese Listed Firms [J].
Journal of Financial Research,2015(12):97-112. (In Chinese)

[7] Zou Hailiang, Jiang Zihan, Shuai Ping. Board Interlocks and Environmental Performance: From the Perspective of Social Networks[J].East China Economic Management,2018,32(03):119-127.(In Chinese)

[8] Yin Jianhua, Wang Sen, Gong Lidong. Research on the relationship between environmental performance and financial performance of heavily polluting firms: The joint moderating effects of firm characteristics and environmental information disclosure $[\mathrm{J}]$. Science Research Management,2020,41(05):202-212.(In Chinese)

[9] Fama E F. Agency problems and the theory of the firm. The journal of political economy, 1980, 88(2): 288-307.

[10] BERRONE P, GOMEZ-MEJIA LR. Environmental Performance and Executive Compensation: An Integrated Agency-Institutional Perspective[J]. Academy of Management Journal,2009;52(1):103-126. 